\title{
PERUBAHAN BERAT BADAN AKSEPTOR KB IMPLANT, SUNTIK DAN PIL DI WILAYAH KERJA PUSKESMAS TERJUN KECAMATAN MEDAN MARELAN
}

\author{
Nova Linda Rambe \\ Universitas Imelda Medan, Indonesia
}

Article Info

Keywords:

Contraceptive Acceptors

Weight Change

Implants

\begin{abstract}
Background Weight change is one of the side effects that are often complained by implants, injection and pill contraceptive acceptor. Weight gain experienced by hormonal contraceptive acceptor is influenced by estrogen and progesterone hormone levels contained in hormonal contraceptive components. PurposeTo find out the weight variative change of implan, injection, and pil acceptorResearch method is Descriptive survey. Sampling technique is purposive sampling amounted to 62 respondents. Results from 62 respondents of family planning acceptors 48 people $(77.4 \%)$ had weight gain, 8 people $(12.9 \%)$ lost weight and 6 people $(9.7 \%)$ did not change body weight. Conclusion Overall implant, injection or pill contraseptives acceptor undergo weight change before and after used the contraceptives. Suggestion Midwife or health worker provide information on the benefits and side effects of using implants, injecting and pill contraceptives on weight when using any of these contraceptives.
\end{abstract}

This is an open access article under the CC BY-SAlicense.

Corresponding Author:
Nova Linda Rambe,
Program Studi D-III Kebidanan,
Universitas Imelda Medan,
Jl. Bilal No. 52 Kelurahan Pulo Brayan Darat I Kecamatan Medan Timur, Medan - Sumatera Utara.
Email: rambenovalinda@ gmail.com

\section{INTRODUCTION}

Kontrasepsi hormonal merupakan salah satu metode KB yang mengandung hormon esterogen dan progesterone untuk mecegah terjadinya kehamilan. Hormon-hormon ini bekerja sebagai penghambat pengeluaran folicel stimulating hormon dan luiteinizing hormone sehingga proses konsepsi terhambat. Metode modern kontrasepsi hormonal terbagi menjadi tiga yaitu kontrasepsi suntik, kontrasepsi pil dan kontrasepsi implant (Manuaba, 2009).

Secara nasional peserta akseptor KB pada bulan Oktober 2013 sebanyak 723.456 Apabila dilihat per mix kontrasepsi maka persentasenya adalah sebagai berikut: IUD (7,39\%), MOW (1,40\%), Implant (11,20\%), Suntikan (46,17\%), Pil (27,06\%), MOP (0,30\%) dan kondom (6,48\%). Mayoritas peserta KB didominasi oleh peserta KB Suntik, Pil dan Implant (BKKBN, 2013).

Didalam bukunya Hanafi Hartanto (2003) tentang Keluarga Berencana dan Kontrasepsi mengatakan bahwa sampai saat ini belum tersedia satu metode kontrasepsi yang benar-benar $100 \%$ ideal/sempurna. 
Seperti halnya bahwa semua kontrasepsi mempunyai kegagalan maka semua kontrasepsi juga menimbulkan resiko tertentu pada pemakainya. Dengan demikian ada 3 (tiga) hal yang sangat penting untuk diketahui oleh calon akseptor KB yakni: efektivitas, keamanan dan efek samping.

Selain memiliki kelebihan alat kontrasepsi juga memiliki kelemahan. Kelemahan dari kontrasepsi antara lain terganggunya pola haid diantaranya adalah amenorhoe, menoragia dan muncul bercak (spotting), terlambatnya kembali kesuburan setelah penghentian pemakaian, pertambahan berat badan $1,5-2 \mathrm{~kg}$ dan berat badan pada kunjungan pertama. Pertambahan berat badan disebabkan oleh retensi cairan, bertambahnya lemak pada tubuh, dan meningkatkan selera makan (Yuhedi, 2011 ; Arum, Sujiyatini, 2014; Manuaba, 2009).

Berdasarkan penelitian yang pernah dilakukan oleh Annisa khoiriah pada agustus 2016 dengan judul hubungan penambahan berat badan pada akseptor kontrasepsi hormonal menunjukkan bahwa penambahan berat badan terjadi pada akseptor kontrasepsi hormonal sebanyak 54 responden (81.8\%) yang mengalami penambahan berat badan, sedangkan yang tidak mengalami penambahan berat badan sebanyak 15 responden $(45,5 \%)$.

Menurut penelitian lain yang berjudul Faktor-faktor yang Mempengaruhi Rendahnya Pengetahuan Ibu untuk Memilih Implant Sebagai Alat Kontrasepsi Di Kelurahan terjun Kecamatan Medan Marelan Tahun 2018 menyatakan setiap faktor masih mempengaruhi ketidak mauan Ibu dalam menggunakan alat kontrasepsi Implant (Hutauruk, 2019).

Menurut BKKBN (2013) terdapat beberapa alasan drop out akseptor KB dari metode KB antara lain: takut efek samping, perceraian, frekuensi hubungan seksual yang jarang, dan kegagalan alat kontrasepsi yang digunakan (Yulitama, 2013). Dari beberapa alasan tersebut efek samping dari alat kontrasepsi merupakan faktor terbesar yang menyebabkan akseptor mengalami drop out dari KB yang digunakan. (http://aplikasi.bkkbn.go.id/sr, diperoleh tanggal 22 Oktober 2016).

Perubahan berat badan merupakan salah satu efek samping dari metode kontrasepsi dan juga merupakan salah satu faktor penyebab akseptor KB mengalami drop out dari alat kontrasepsi yang digunakan. Hasil SDKI 2012, angka ketidaklangsungan (drop out) dari tahun 2003 sampai 2007 adalah pengguna metode Pil dari 38,8\% menjadi 31,9\%, pengguna Suntik dari $23 \%$ menjadi 18,4\% dan pengguna Implan dari $5,7 \%$ menjadi $2,7 \%$. Berdasarkan latar belakang diatas maka peneliti tertarik untuk meneliti variasi perubahan berat badan akseptor KB Implant, suntik, dan Pil di Puskesmas Terjun Kecamatan Medan Marelan.

\section{RESEARCH METHOD}

Penelitian ini menggunakan desain penelitian survey deskriptif untuk mengetahui variasi perubahan berat badan akseptor KB Implan, Suntik, dan Pil. Penelitian dilakukan di Wilayah Kerja Puskesmas Terjun Kecamatan Medan Marelan sebanyak 62 orang. Pengambilan sampel penelitian dilakukan secara puerposive sampling.

Subjek penelitian ini memiliki kriteria inklusi yaitu ibu yang telah menggunakan alat kontrasepsi selama 6 bulan pada dan ibu yang telah ditimbang berat badannya pada saat sebelum pemakaian KB serta masih mengingat berat badan tersebut. Instrumen yang digunakan adalah check list observasi. Analisis data dilakukan menggunakan presentase.

\section{RESULTS AND ANALYSIS}

\subsection{Hasil}

Hasil pengumpulan data dan pengolahan data yang dilakukan oleh peneliti tentang "Variasi Perubahan Berat Badan Akseptor KB Implan, Suntik dan Pil diwilayah Kerja Puskesmas Terjun" pada bulan Maret - April 2019 dengan jumlah responden 62 orang menggunakan lembar check list observasi, maka hasilnya diuraikan sebagai berikut:

Tabel 1. Distribusi Akseptor KB Implan berdasarkan Perubahan Berat Badan

\begin{tabular}{cccc}
\hline No. & Perubahan berat badan & Frekuensi (f) & Presentase (\%) \\
\hline 1 & Menetap & 0 & 0 \\
\hline 2 & Meningkat & 20 & 100 \\
\hline 3 & Menurun & 0 & 0 \\
\hline & Total & 20 & 100 \\
\hline
\end{tabular}

Dari tabel diatas dapat diketahui bahwa dari 20 responden akseptor KB Implan keseluruhan responden 20 orang $(100 \%)$ mengalami kenaikan berat badan. 
Tabel 2. Distribusi akseptor KB Suntik berdasarkan Perubahan Berat Badan

\begin{tabular}{cccc}
\hline No. & Perubahan berat badan & Frekuensi (f) & Presentase (\%) \\
\hline 1 & Menetap & 1 & 3,8 \\
\hline 2 & Meningkat & 19 & 73,1 \\
\hline 3 & Menurun & 6 & 23,1 \\
\hline & Total & $\mathbf{2 6}$ & $\mathbf{1 0 0}$ \\
\hline
\end{tabular}

Tabel diatas dapat diketahui dari 26 responden akseptor KB suntik mayoritas mengalami kenaikan berat badan sebanyak 19 orang $(73,1 \%)$ dan hanya 1 orang $(3,8 \%)$ yang berat badan menetap.

Tabel 3. Distribusi akseptor KB Pil Berdasarkan Perubahan Berat Badan

\begin{tabular}{cccc}
\hline No. & Perubahanberat badan & Frekuensi (f) & Presentase (\%) \\
\hline 1 & Menetap & 5 & 31,2 \\
\hline 2 & Meningkat & 9 & 56,3 \\
\hline 3 & Menurun & 2 & 12,5 \\
\hline & Total & $\mathbf{1 6}$ & $\mathbf{1 0 0}$
\end{tabular}

Tabel diatas dapat diketahui bahwa dari 16 responden akseptor KB pil, perubahan berat badan sebagian besar mengalami kenaikan sebanyak 9 orang $(56,3 \%)$ dan sebagian kecil mengalami penurunan berat badan sebanyak 2 orang $(12,5 \%)$.

Tabel 4. Distribusi Frekuensi Variasi Perubahan Berat Badan Akseptor KB Implan, Suntik dan Pil

\begin{tabular}{cccccccccc}
\hline \multirow{2}{*}{ No } & Akseptor & \multicolumn{9}{c}{ Perubahan BB } & \multicolumn{2}{c}{ Jumlah } \\
\cline { 3 - 8 } & & \multicolumn{2}{c}{ Menetap } & \multicolumn{2}{c}{ Meningkat } & \multicolumn{2}{c}{ Menurun } & & \\
\cline { 2 - 8 } & & $\mathbf{f}$ & $\mathbf{\%}$ & $\mathbf{F}$ & $\mathbf{\%}$ & $\mathbf{f}$ & $\mathbf{\%}$ & F & \% \\
\hline 1 & Implan & 0 & 0 & 20 & 100 & 0 & 0 & 20 & 32,2 \\
\hline 2 & Suntik & 1 & 3,8 & 19 & 73,1 & 6 & 23,1 & 26 & 42 \\
\hline 3 & Pil & 5 & 31,3 & 9 & 56,3 & 2 & 12,5 & 16 & 25,8 \\
\hline & Jumlah & $\mathbf{6}$ & $\mathbf{9 , 7}$ & $\mathbf{4 8}$ & $\mathbf{7 7 , 4}$ & $\mathbf{8}$ & $\mathbf{1 2 , 9}$ & $\mathbf{6 2}$ & $\mathbf{1 0 0}$ \\
\hline
\end{tabular}

Berdasarkan tabel diatas dapat diketahui bahwa dari 62 responden terdapat 20 responden akseptor KB Implan keseluruhan mengalami kenaikan berat badan sebanyak 20 orang (100\%), 26 orang akseptor KB suntik mayoritas mengalami kenaikan berat badan sebanyak 19 orang $(73,1 \%)$ dan 16 orang akseptor KB Pil mayoritas mengalami peningkatan berat badan ssebanyak 9 orang $(56,3 \%)$.

\subsection{Pembahasan}

\section{Variasi Perubahan Berat Badan Akseptor KB Implan}

Berdasarkan hasil penelitian dapat diketahui bahwa dari 20 responden akesptor KB Implan keseluruhan responden mengalami peningkatan berat badan.Berat badan merupakan salah satu indikator untuk menentukan status gizi seseorang. Berat badan merupakan indikator status gizi yang mudah berubah. Banyak sekali faktor yang dapat menyebabkan perubahan berat badan seseorang.

Sutarna dkk (2009) menyatakan efek samping yang mungkin terjadi dari pemakaian implant adalah penambahan berat badan yang signifikan. Ayurai (2009) juga menyatakan keterbatasan implant salah satunya adalah peningkatan atau penurunan berat badan. Kenaikan berat badan tersebut akibat pengaruh aktifitas androgenik LNG berupa efek metabolik yang menyebabkan peningkatan nafsu makan (Hanafi, 2008). Sedangkan kenaikan berat badan terjadi karena hormon ini mempengaruhi proses metabolisme lemak dan kolesterol dalam tubuh (Piogama, 2009). Efek ini tergantung pada potensi androgennya. Makin kuat potensi androgennya, makin besar efek buruknya pada metabolisme lemak (Mariyono, 2003).

Metabolisme lemak merupakan salah satu faktor penentu dalam peningkatan berat badan. Pemakaian KB hormonal dapat meningkatkan proses pembentukan kolesterol dan lemak. Tetapi efek samping ini bersifat individual karena ada beberapa orang yang menggunakan KB implant tetapi tidak mengalami kenaikan berat badan. Perbedaan berat badan yang terjadi pada akseptor KB implant adalah adanya efek samping yang ditimbulkan dari livonorgestrel. Levonorgestrel mempengaruhi peningkatan nafsu makan. Selain itu Levonorgestrel juga mempengaruhi metabolisme lemak dan kolesterol dalam tubuh.Sebagian wanita yang menggunakan implant mengalami efek samping kenaikan berat badan (Wulansari dan Hartanto, 2007). Dua faktor eksternal yang sangat dominan mempengaruhi berat badan adalah aktivitas fisik dan asupan nutrisi.

\section{Variasi Perubahan Berat Badan Akseptor KB Suntik}

Berdasarkan hasil penelitian dapat diketahui dari 26 responden akseptor $\mathrm{KB}$ suntik mayoritas mengalami peningkatan berat badan sebanyak 19 orang $(73,1 \%)$ dan hanya 1 orang yang berat badan 
menetap. Kenaikan berat badan pada sebagian besar akseptor KB suntik terjadi setelah pemakaian lebih dari 6 bulan -1 tahun pemakaian. Hal tersebut merupakan salah satu faktor penyebab adanya peningkatan berat badan pada sebagan besar akseptor KB suntik DMPA. Hal tersebut sesuai dengan pendapat Nurjanah (2006), yang menyatakan bahwa risiko kenaikan berat badan ini tidak ada perbedaan pada 12 bulan pertama penggunaan. Semakin lama menggunakanKB hormonal maka risiko terjadinya obesitas akan semakin besar. Menurut teori yang dikemukakan oleh Hartanto (2004) juga menyatakan bahwa dari pemakaian kontrasepsi suntik jangka waktu yang lama dapat menyebabkan kenaikan berat badan karena adanya kandungan hormon progesteron yang dapat meningkatkan nafsu makan bertambah apabila pemakaian dosis yang tinggi atau berlebihan karena dapat merangsang pusat pengendali nafsu makan di hipotalamus yang menyebabkan akseptor makan lebih banyak dari biasanya.

Peningkatan berat badan pada penggunaan kontrasepsi suntik bulanan efek samping terhadap berat badan sangatlah ringan, rata-rata pertambahan berat badan dua hingga tiga kilogram pada tahun pertama pemakaian dan terus bertambah selama tahun kedua (Hartanto, 2003; Varney, 2007).

Berdasarkan penjelasan teori di atas dapat disimpulkan bahwa ada perbedaan berat badan sebelum dan setelah penggunaan kontrasepsi suntik. Pemakaian kontrasepsi kontrasepsi suntik mempunyai efek samping utama yaitu perubahan berat badan. Hal ini disebabkan karena kontrasepsi suntik yang mengandung progesterone atau medroksiprogesteron sebanyak $150 \mathrm{mg}$ dalam bentuk partikel kecil (Manuaba, 2007). Hormon progesteron yang kuat mampu merangsang hormon nafsu makan yang ada di hipotalamus. (Mansjoer, 2003).

\section{Variasi Perubahan Berat Badan Akseptor KB Pil}

Berdasarkan hasil penelitian diketahui dari 16 responden akseptor KB Pil sebagian besar mengalami kenaikan berat badan sebanyak 9 orang $(56,3 \%)$ dan sebagian kecil mengalami penurunan berat badan sebanyak 2 orang ( $12,5 \%)$. Kontrasepsi oral, yang biasa dikenal dengan Pil KB (terkadang 'Pil' saja) mengandung hormone, baik kombinasi hormone progestin dan estrogen maupun hormone progestin saja. Pil adalah metode kontrasepsi yang mengandung hormone steroid (progestero dan estrogen sintetik/progesterone sintetik saja) yang digunakan peroral.

\section{Variasi Perubahan Berat Akseptor KB Implan, Suntik Dan Pil}

Berdasarkan tabel 4 dapat diketahui bahwa dari 62 responden akseptor KB implan, suntik dan pil terdapat 20 responden akseptor KB Implan keseluruhan mengalami peningkatan berat badan sebanyak 20 orang $(100 \%)$, dari 26 orang akseptor KB suntik mayoritas mengalami peningkatan berat badan sebanyak 19 orang $(73,1 \%)$ dan dari 16 orang akseptor KB Pil mayoritas mengalami peningkatan berat badan ssebanyak 9 orang $(56,3 \%)$.

Penelitian ini juga sejalan dengan penelitian yang pernah dilakukan oleh Annisa khoiriah pada agustus 2016 dengan judul hubungan penambahan berat badan pada akseptor kontrasepsi hormonal menunjukkan bahwa penambahan berat badan terjadi pada akseptor kontrasepsi hormonal sebanyak 54 responden $(81.8 \%)$ yang mengalami penambahan berat badan, sedangkan yang tidak mengalami penambahan berat badan sebanyak 15 responden $(45,5 \%)$.

Menurut Hartanto (2003) Kenaikan berat badan tidak terlalu besar, bervariasi antara kurang dari satu kilogram sampai lima kilogram dalam tahun pertama. Peningkatan berat badan terjadi karena bertambahnya lemak tubuh dan bukan karena retensi cairan tubuh. Peningkatan berat badan pada pemakaian kontrasepsi hormonal lebih dari 2,3 kilogram pada tahun pertama dan selanjutnya meningkat secara bertahap hingga mencapai 7,5 kilogram selama enam tahun (Varney, 2007).

Pertambahanberat badan disebabkan oleh hormon estrogen dan progesteron yang ada dalam pildalam penggunaan jangka waktu tertentu. Progesteron juga dapat menyebabkanpertambahan berat pada penggunaan yang lama.

\section{CONCLUSION}

Berdasarkan hasil penelitian serta pembahasan yang disertai dengan teori dan hasil penelitian lain yang mendukung mengenai Variasi Perubahan Berat Badan Akseptor KB Implan, Suntik dan pil diwilayah Kerja Puskesmas Terjun Kecamatan Medan Tembung, maka diperoleh kesimpulan adanya peningkatan berat badan pada akseptor KB impaln, suntik dan pil.

\section{REFERENCES}

Arikunto, S. (2010). Prosedur Penelitian Suatu Pendekatan Praktik. Jakarta: Rineka Cipta.

Arum, D. N. S., \& Sujiyatini (2014). Panduan lengkap pelayanan KB terkini. Yogyakarta: Nuha Medika.

BKKBN, (2013). Laporan umpan balik pelayanan kontrasepsi. http://aplikasi.bkkbn.go.id/sr, diperoleh tanggal 22 Oktober 2016. 
Budiyanto, (2012). Mencegah kekanaikan berat badan akibat KB hormnal. http://blogspot.co.id/2014/11/mencegah-kegemukan-yang-disebabkan-oleh-hormon.html, diperoleh tanggal 03 Juni 2017.

Cipto Surono, (2000). Pengertian Berat Badan. https://pengertianberatbadan.wordpress.com/ diperoleh tanggal 19 oktober 2016.

Ganong, (2003). Hubungan antara hormon dan berat badan http://ehormon.blogspot.co.id/2014/11/hubungan-antara-hormon-dan-berat-badan.html, diperoleh tanggal 03 Juni 2017.

Hartanto, (2003), pengertian Akseptor KB. http://wawanjokamblog.blogspot.co.id/2009/07/akseptor-kb.html, diperoleh tanggal 22 Oktober 2016.

Hastono. P. S. , Sabri. L., (2010) Statistik Kesehatan Jakarta : PT Raja Grafindo Persada.

Hutauruk, P. M. (2019). FAKTOR - FAKTOR YANG MEMPENGARUHI RENDAHNYA PENGETAHUAN IBU UNTUK MEMILIH IMPLANT SEBAGAI ALAT KONTRASEPSI DI KELURAHAN TERJUN KECAMATAN MEDAN MARELAN TAHUN 2018. Jurnal Ilmiah Kebidanan Imelda, 5(1), 606-611.

Manuaba. I. A. C. , ((2009). Memahami kesehatan reproduksi wanita. Edis 2 : Jakarta : ECG.

Notoatmodjo.S., (2010).Metodologi penelitian kesehatan Jakarta : Rineka Cipta

Nugroho.T. \& Utama. I. B. Dr., (2014). Masalah kesehatan reproduksi wanita. Yogyakarta : Nuha Medika.

Kepmenkes RI, (2013), Situasi keluarga berencana di Indonesia. http//buletin-kespro.pdf. diperoleh tanggal 23 Oktober 2013.

Sibagariang,E., Pusmaika R., \& Rismalinda, (2010). Kesehatan Reproduksi wanita : Jakarta Timur : CV. Trans Info Media.

Siregar, E. (2009) Hubungan Antara penggunaan alat kotrasepsi suntik 3 bulan dengan Pertambhan berat badan akseptor KB.Jurnal kebidanan haga,2(4) Juni, 4-5.

Soetjiningsih, (1995), Pengertian Berat Badan.https://pengertianberatbadan.wordpress.com/di diperoleh 19 Oktober 2016.

Suparyanto, dr. (2010), Pengertian berat badan http://dr-suparyanto.blogspot.co.id/2010/12/pengaruh-kbsuntik-terhadap-perubahan.html, diproleh tanggal 22 Oktober 2016.

Surono C., 2009, pengertian berat badan. https://pengertianberatbadan.wordpress.com/diakses tanggal 19 oktober 2016.

Udin S. Winataputra, (2004), Pengertian Variasi. http://ghufron-dimyati.blogspot.co.id, diperoleh tanggal 05 November 2016.

Yanti, (2014) Buku ajarkesehatan reproduksi untuk mahasiswi kebidanan Yogyakarta : Pustaka Rihama.

\section{BIOGRAPHIES OF AUTHORS}

\begin{tabular}{l|l|} 
Nova Linda Rambe, Gelar D-III diperoleh dari Akademi Kebidanan Darmo, Jurusan \\
Kebidanan pada tahun 2009. Gelar D-IV diperoleh dari Universitas Padjadjaran, \\
Jurusan Kebidanan Tahun 2011. Magister Kebidanan diperoleh dari Universitas \\
Padjadjaran, Jurusan Kebidanan pada tahun 2017. Saat ini aktif sebagai dosen tetap di \\
Prodi S1 Kebidanan Universitas Imelda Medan dan menjabat sebagai Ketua Program \\
Studi.
\end{tabular}

